\title{
The effect of ashes on the properties of cement mortar and typical concrete fillers
}

\author{
Janina Setina ${ }^{1}$, Inna Juhnevica ${ }^{2}$, Janis Baronins ${ }^{3}$ \\ Institute of Silicate Materials, Riga Technical University, Paula Valdena 3, LV-1048, Riga, Latvia \\ E-mail: 'janina.setina@rtu.lv (correspondingauthor)
}

\begin{abstract}
The production of heat and electricity from shale and biomass is leading to a significant increase in the amount of the combustion residues i.e. ashes. The utilization of ashes as the pozzolanic additive in the production of Portland cement mortar and concrete for the construction of lightweight structures is the most popular way. The interaction of ashes with other typical concrete fillers also can affect the final relative short-term and long-term properties of fresh and hardened concrete when designing the concrete mixture.

The influence of wood and shale ashes on the properties of cement mortar and typical concrete fillers (sand, limestone, dolomite) - fresh mortar, hydration process, and hardened mortar were researched and assessed for their applicability in the production of concrete.

The best results of mechanical strength, frost resistance and water absorption were measured in case of shale ashes containing samples in combination with cement and selected concrete additive - sand.

Shale ashes can be recommended for application as the active additive. Since wood ash was exhibiting lower activity, it can also be applied as a filler to produce building materials.
\end{abstract}

Keywords: shale ash, wood ash, concrete, pozzolanic activity.

\section{Introduction}

Ashes are one of the largest combustion products and the greatest environmental polluting waste from coal-based fuel (a non-renewable resource) and cogeneration plant (a renewable resource) (Sear, 2001). Attention to renewable energy resources increases due to constant growth of energy consumption. Structures and sizes of ash particles depend on a type of raw materials, processing temperature, and other conditions commonly occurring in the combustion chamber (Fenelonov, Mel'gunov, \& Parmon, 2010; Chowdhury, Mishra, \& Suganya, 2015).

The application of ashes depends on the purity and chemical properties regulated by number of preconditions. Firstly, an ash is a by-product and application or disposal of this waste in industry may lead to a possibly reduced and controlled environmental pollution. Secondly, ashes are widely applied as raw materials for production of cemented composites in lightweight concrete and mortar constructions made of cement (e.g. Portland cement with enhanced durability in composition with ashes) and acid resistive geopolymer based materials made of ashes (Wesche, 1991; Lilkov, Djabarov, Bechev, \& Petrov, 1999). The substitution of silt with a cementitious material and stabilization of soil is a reasonable way for utilization of ashes (Association, A. C. A., 2004; Siddique, 2012). Soil stabilization has a wide range of benefits and causes demands for low cost and easily available ashes in today's construction industry (Zaetang, Wongsa, Sata, \& Chindaprasirt, 2013). Finding ways to utilize ashes in an environmentally and economically efficient manner is thus an important goal throughout Europe.

Coal, burnstone and petroleum products are most commonly consumed as the part of non-renewable or fossil fuel resources. Limited quantities of these fuels and the emissions of greenhouse gases $\left(\mathrm{CO}_{2}, \mathrm{CH}_{4}, \mathrm{NO}_{\mathrm{X}}, \mathrm{SO}_{\mathrm{X}}\right.$, etc.) in the combustion process increases the demand for renewable fuels.

Two classes of ashes (class F - less active, and class C - active pozzolana) have been specified in ASTM C618. Fly ash has superior properties, including low density, good packing factor, enhanced thermal and sound insulation properties, improved flow characteristics, low water absorption and high chemical inertness (Jozic \& Zelic, 2006).

Properties and performance of the ash-containing lightweight products depend on several major physical structure parameters like diameter, fineness, wall thickness and shape of ash particles (Landman, 2005). Replacement of Portland cement with ashes in concrete structure often leads to decreased permeability of adversely affecting ions. This effect relates to more fine particle size distribution when concrete cures (Wesche, 1991).

(C) 2019 Authors. Published by VGTU Press. This is an open-access article distributed under the terms of the Creative Commons Attribution (http://creativecommons.org/licenses/by/4.0/) License, which permits unrestricted use, distribution, and reproduction in any medium, provided the original author and source are credited. 
Wood chips are a large part of biomass commonly combusted in cogeneration plants as a renewable fuel resource. Cogeneration process combines the production of heat and electricity at the same time. It leads to significantly lower consumption of fuel as compared with the separated production of heat and electricity (Obernberger \& Supancic, 2009).

Combustion process results in the heterogeneous composition of obtained ash consisting of different trimming fractions: heavy ash (bottom ash), coarse ash and light ash (e.g., fly ash, cenospheres, etc.). Heavy ash commonly forms during fluidized bed combustion due to contamination of bed material (e.g., sand or limestone) with combustion products. The coarse ash commonly forms in cyclone ovens and collects during fume filtration in baghouses or electrostatic precipitators with inhomogeneous particle size distribution (Fenelonov et al., 2010).

Pozzolanic activity of shale and wood ashes in reactive mixture commonly depends on the chemical composition and particle sizes (fineness) (Ayub, Shafiq, \& Khan, 2013).

Generally, pozzolans are natural or synthetic fine-grained substances consisting of reactive $\mathrm{SiO}_{2}$ or $\mathrm{Al}_{2} \mathrm{O}_{3}$ as essential constituents, which react with calcium hydroxide from Portland cement or other mineral materials in the presence of water and form calcium silicates or aluminate hydrates. The concentration of active $\mathrm{SiO}_{2}$ or $\mathrm{Al}_{2} \mathrm{O}_{3}$ and free $\mathrm{CaO}$ significantly influences the pozzolanic activity of ashes from non-reactive up to pozzolanic and even self- cementitious capabilities (ACI E4, 2003).

Hydration products fill interstitial pores and subsequently reduce the permeability of the concrete matrix. Therefore, the content of reactive compounds in the chemical composition enables the application of ashes as pozzolanic or mechanical fillers in the production of concrete. Insufficient hydration heat of fly ash spheres with a low content of $\mathrm{CaO}$ leads to seasonal limitations in states with cold climate. Low early hydration rate causes the reduced early construction strength and durability of hardened concrete (Aitcin, 2007; Jain, 2012).

The aim of this study was to obtain scientifically evidence that could be useful in the construction practice for manufacturing of Portland cement composites with typical additive-based concrete by using shale and wood ashes, leading to reduced environmental pollution.

\section{Experimental process and raw materials}

Three types of ashes were tested:

- shale ash was delivered from the oil shale-fired thermal power plant "Narva Power Plant" (Narva, Estonia);

- wood ash was delivered from wood chips-fired biomass cogeneration plant "Fortum" (Jelgava, Latvia);

- shale ash was from sub-bituminous shale-fired electric power station "INOTEK" (Russian Federation).

Cenospheres from "INOTEK" with defects were grinded in planetary ball mill "Retch PM 400" for 6 hours, and subsequently the effect of grain size on pozzolanic activity was estimated.

Four mineral materials were selected for tests:

- Aalborg White CEM I 52.5R cement (Germany),

- sand (Ltd. "Sacret", dispersion 0-1 mm),

- dolomite (Ltd. "Saulkalne", dispersion $<1 \mathrm{~mm}$ ),

- lime (Ltd. "Saulkalne", dispersion $<1 \mathrm{~mm}$ ),

Experiments were carried out with following dry mix composition as shown in Table 1.

A chemical analysis was determined according to LVS EN 196-2:2005.

Pozzolanic activity of ashes was determined with a help of adapted chemical method according to Costa and Massazza ((Massazza, 1980). Pozzolanic activity was tested after 3, 7, 24 hours, 3, 7, 14, 28 days of reaction with $\mathrm{Ca}(\mathrm{OH})_{2}$.

The following methodology for fresh mix compositions were used:

- flow ability according to LVS EN 1015-2:2007;

- density of raw ash paste, LVS EN 1015-6:2007;

- porosity of raw ash paste, LVS EN 1015-7:2003.

Mix compositions (ashes + mineral materials) were made to test mechanical and physical properties. Dry mix was mixed with water, filled in moulds ( $4 \times 4 \mathrm{~cm}$ cylinders) and were cured for 28 days. Hardened specimens were tested:

- water absorption of specimens according to LVS EN ISO 15148:2003;

- bulk density according to LVS EN 1015-10:2007;

- the mineralogical composition of ashes, mineral raw materials and mix composition by X-Ray Diffraction (diffractometer Rigaku Optima Plus) using $\mathrm{CuK} \alpha$ radiation;

- SEM analysis was performed with a microscope HITACHI Tabletop TM-3000 - HisScope;

- surface area (pore size 35-200 nm) was made by BET (Nova 1200 E-Series, Quantachrome Instruments).

The samples of cement pastes were prepared with water-to-cement ratio of 0.4 . The samples of concrete fillers (sand, lime, dolomite) pastes were prepared with different content of water. 
The standard laboratory mixing device was used for the preparation of compositions (the content of ashes was 10, 20, and $40 \mathrm{wt}$. \%) according to mix design as shown in Table 1. After demoulding, samples were cured for 28 days at $+20 \pm 1{ }^{\circ} \mathrm{C}$ temperature under $100 \%$ humidity environmental conditions.

Table 1. The mix compositions

\begin{tabular}{|c|c|c|c|c|}
\hline \multicolumn{3}{|c|}{ Designation of samples } & \multicolumn{2}{|c|}{ Composition } \\
\hline Wood ash (J) & Shale ash $(\mathrm{N})$ & Shale ash (I) & Content of ash [wt. \%] & Selected mineral material \\
\hline $40 \mathrm{JC}$ & $40 \mathrm{NC}$ & $40 \mathrm{IC}$ & 40 & \\
\hline 20JC & $20 \mathrm{NC}$ & 20IC & 20 & cement \\
\hline $10 \mathrm{JC}$ & $10 \mathrm{NC}$ & $10 \mathrm{IC}$ & 10 & \\
\hline 40JS & $40 \mathrm{NS}$ & 40IS & 40 & \\
\hline 20JS & $20 \mathrm{NS}$ & 20IS & 20 & sand \\
\hline $10 \mathrm{JS}$ & $10 \mathrm{NS}$ & $10 \mathrm{IS}$ & 10 & \\
\hline $40 \mathrm{JK}$ & $40 \mathrm{NK}$ & $40 \mathrm{IK}$ & 40 & \\
\hline $20 \mathrm{JK}$ & $20 \mathrm{NK}$ & $20 \mathrm{IK}$ & 20 & lime \\
\hline $10 \mathrm{JK}$ & $10 \mathrm{NK}$ & $10 \mathrm{IK}$ & 10 & \\
\hline 40JD & 40ND & 40ID & 40 & \\
\hline 20JD & $20 \mathrm{ND}$ & 20ID & 20 & dolomite \\
\hline 10JD & $10 \mathrm{ND}$ & 10ID & 10 & \\
\hline
\end{tabular}

\section{Results and discussion}

The properties of ashes

When studying the effects of ashes, i.e. cementing materials on concrete mineral ingredients (cement, sand, lime, dolomite), it is important to explore the structure and chemical composition of ashes.

Table 2. Chemical composition of ashes, wt.\%

\begin{tabular}{|l|c|c|c|}
\hline Components & Wood ash $(\mathrm{J})$ & Shale ash from Narva $(\mathrm{N})$ & Shale ash "INOTEK" (I) \\
\hline $\mathrm{SiO}_{2}$ (all) & $42.4-46.5$ & $28.6-30.9$ & $55.8-56.4$ \\
\hline $\mathrm{SiO}_{2}$ (active) & $3.00-3.50$ & $10.0-10.15$ & $8.3-8.8$ \\
\hline $\mathrm{CaO}$ & $22.7-24.6$ & $29.3-31.3$ & $1.9-2.3$ \\
\hline $\mathrm{MgO}$ & $1.61-3.27$ & $1.77-2.62$ & $0.9-1.1$ \\
\hline $\mathrm{Al}_{2} \mathrm{O} 3$ & $1.02-1.08$ & $12.8-12.9$ & $37.9-38.6$ \\
\hline $\mathrm{Fe}_{2} \mathrm{O}_{3}$ & $1.15-1.26$ & $4.42-12.87$ & $1.5-1.7$ \\
\hline $\mathrm{K} 2 \mathrm{O}$ & $4.35-7.85$ & $4.30-5.21$ & $0.3-0.5$ \\
\hline $\mathrm{Na}_{2} \mathrm{O}$ & $0.65-1.65$ & $2.05-2.94$ & $0.7-0.8$ \\
\hline $\mathrm{Hydr}$ modulus & $1.73-2.00$ & $2.10-2.15$ & $0.029-0.031$ \\
\hline
\end{tabular}

Chemical analysis of shale $(\mathrm{N})$ and wood $(\mathrm{J})$ ashes indicates the significant amount of active $\mathrm{SiO}_{2}, \mathrm{Al}_{2} \mathrm{O}_{3}$, and high amount of $\mathrm{CaO}$, Table 2. The low content of $\mathrm{CaO}$ and $\mathrm{R}_{2} \mathrm{O}$ was found to be the characteristic parameter of ash from electric power station "INOTEK" (I). According to the ASTM C618 classification, shale ash (N) corresponds to the ash of class $\mathrm{C}$, while the shale ash (I) corresponds to class $\mathrm{F}$.

In the case of wood ash, the size of particles was measured from 50 up to $60 \mu \mathrm{m}$. Low variability was determined in the case of shale $(\mathrm{N})$ ash with the size of particles from 6 up to $7 \mu \mathrm{m}$, Table 3 .

The highest size of particles from 1 up to $195 \mu \mathrm{m}$ was measured in the case of generally cenosphere structured ash from power plant (I), indicating highest size distribution, as compared with other ashes. The ash consists of cenospheres with a mean size of 50-195 $\mu \mathrm{m}$ and crumbled cenospheres. Further studies to determine the activity of these ash have required the removal of crumbled particles and grinded $6 \mathrm{~h}$ till the size of shale ash (I) was $0.3-12 \mu \mathrm{m}$.

Table 3. Surface area and dispersion of ashes

\begin{tabular}{|l|c|c|c|}
\hline & Wood ash $(\mathrm{J})$ & Shale ash $(\mathrm{N})$ & Shale ash (I) \\
\hline Dispersion, $\mu \mathrm{m}$ & $50-60$ & $6-7$ & $\begin{array}{c}7-195 \text { (without grinding) } \\
0.3-12 \text { (grinding } 6 \mathrm{~h} \text { ) }\end{array}$ \\
\hline Surface area, $\mathrm{m}^{2} \mathrm{~g}$ & 5.027 & 1.017 & 1.205 \\
\hline
\end{tabular}


According to XRD test results investigated ashes characterized different crystalline phases. As can be seen from the resulting XRD test, Table 4, the ashes are a complex system consisting of a large number of crystalline phases. Crystalline phases of lime, calcite, anhydrite, portlandite, plagioclaza, akermanite, dolomite and quartz have been detected in the wood $(\mathrm{J})$ and shale $(\mathrm{N})$ ashes composition. In addition to these phases, the wood ash $(\mathrm{J})$ also contains potassium calcium silicate and the shale ashes $(\mathrm{N})$ are larnite and calcium aluminate. The shale ash (I) that contend high amount of $\mathrm{Al}_{2} \mathrm{O}_{3}$ characterized one crystalline phase - mullite but $\mathrm{SiO}_{2}$ is in an amorphous state, Figure 1.

Table 4. Crystalline phase of wood (J) and shale (N) ashes

\begin{tabular}{|c|c|c|}
\hline Crystalline phases & $\begin{array}{l}\text { Wood } \\
\text { ash }(J)\end{array}$ & $\begin{array}{c}\text { Shale } \\
\text { ash }(\mathrm{N})\end{array}$ \\
\hline Lime $(\mathrm{CaO})$ & + & + \\
\hline Calcite $\left(\mathrm{CaCO}_{3}\right)$ & + & + \\
\hline Anhydrite $\left(\mathrm{CaSO}_{4}\right)$ & + & + \\
\hline Portlandite $\left(\mathrm{Ca}(\mathrm{OH})_{2}\right)$ & + & + \\
\hline Plagioclase $\left(\mathrm{Ca}_{0,65} \mathrm{Na}_{0,35}\left(\mathrm{Al}_{1,65} \mathrm{Si}_{2,35} \mathrm{O}_{8}\right)\right.$ & + & + \\
\hline Quartz $\left(\mathrm{SiO}_{2}\right)$ & + & + \\
\hline Akermanite $\left(\mathrm{Ca}_{2} \mathrm{MgSi}_{2} \mathrm{O}_{7}\right)$ & + & - \\
\hline Dolomite $\left(\mathrm{CaMg}\left(\mathrm{CO}_{3}\right)_{2}\right)$ & - & + \\
\hline Potassium Calcium Silicate $\left(\mathrm{K}_{4} \mathrm{CaSi}_{3} \mathrm{O}_{9}\right)$ & + & - \\
\hline Larnite $\left(\mathrm{Ca}_{2} \mathrm{SiO}_{4}\right)$ & - & + \\
\hline Calcium Aluminate $\left(\mathrm{Ca}_{8} \mathrm{Al}_{3} \mathrm{O}_{12.5}\right)$ & - & + \\
\hline
\end{tabular}

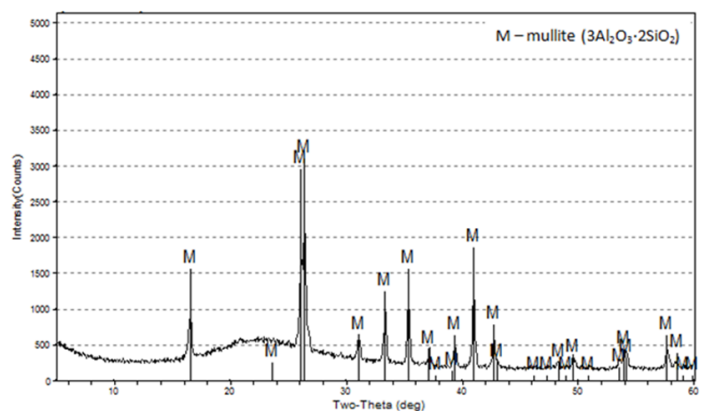

Figure 1. XRD of shale ash (I). Crystalline phase - mullite

\section{SEM investigation of ashes}

The difference in size of ashes particles is related with the observed morphology of particles - wood ash particles have porous surface which may indicate a high presence of an amorphous component. Morphology of ashes (I, J) from shales was different and mutually similar. Here is spherical particles with a smooth surface, Figure 2 . The walls of crushed spheres of ashes (I) contained a small bubbles and some particles were found in shape of plerospheres.
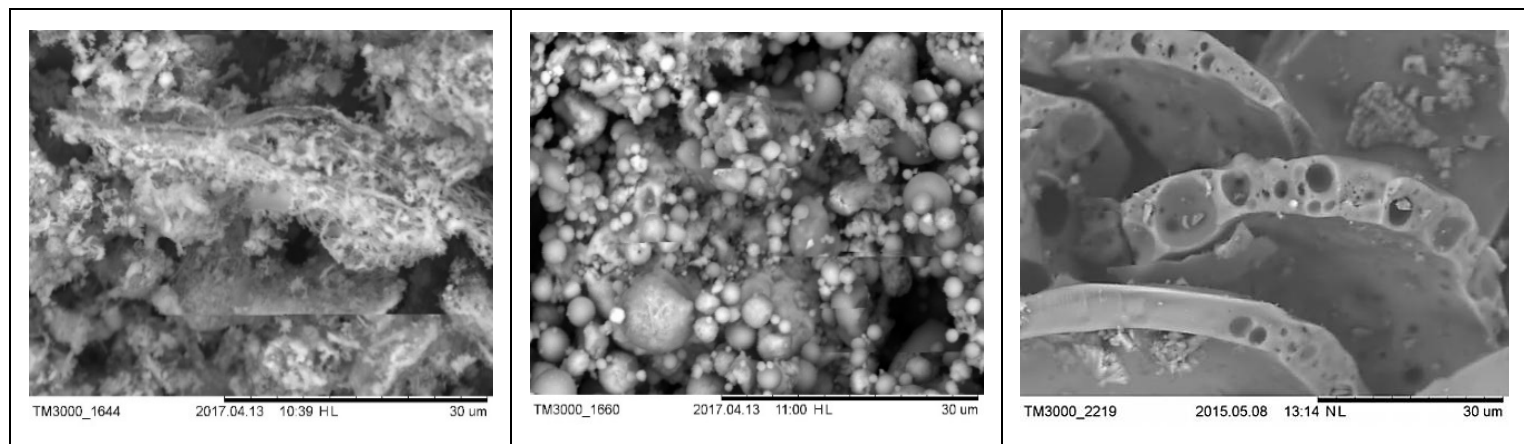

Figure 2. SEM of ashes: 1 - wood ash (J) and 2 - shale ash (N); 3 - shale ash (I)

\section{Pozzolanic activity}

Next step of investigation was to determine activity of ashes. Pozzolanic activity, expressed as the amount of spent reactive $\mathrm{CaO}$ after 1, 3, 7, 14 and 28 days, was tested. The measurements of pozzolanic activity are based on the reaction between free lime and ashes. It is the simplest way how to follow the dynamics of pozzolanic reaction - either to measure the amount of calcium hydroxide or the amount of un-reacted pozzolana. Pozzolanic activity characterizing the capacity of ashes to react with $\mathrm{Ca}(\mathrm{OH})_{2}$ and is indicated in Figure 3.

The chemical composition of ash must be considered, when calculating pozzolanic activity, the high CaO content for $(\mathrm{J})$ and $(\mathrm{N})$ ashes. In parallel, ashes activity in water was determined and results were appropriately co-ordinated following ashes treatment in $\mathrm{Ca}(\mathrm{OH})_{2}$ solution. 


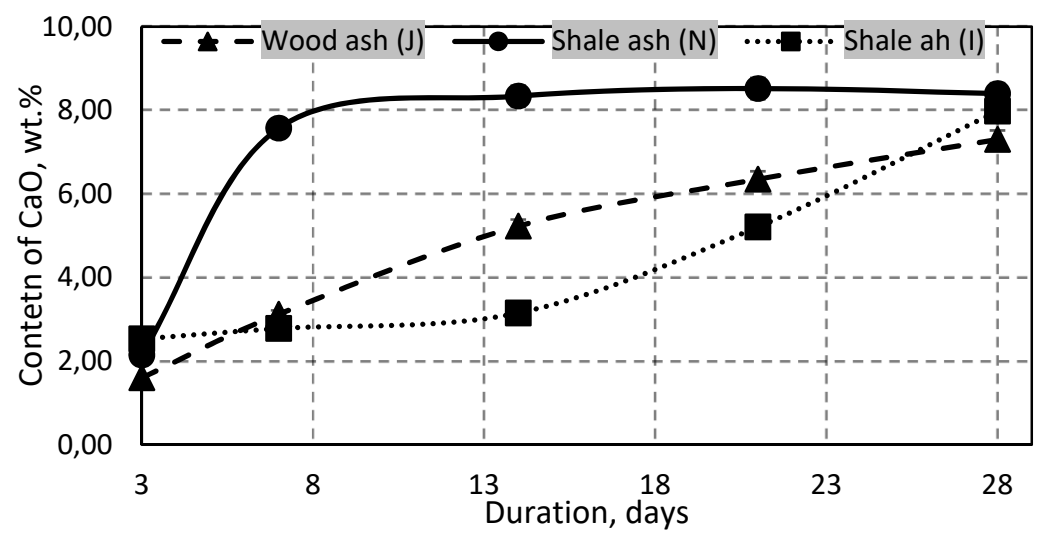

Figure 3. Pozzolanic activity of ashes: 1 - shale ash (N); 2 - wood ash (J); 3 - shale ash (I)

Pozzolanic activity of ashes increase with time of treatment in $\mathrm{Ca}(\mathrm{OH})_{2}$ solution. The maximum value shale ash (N) is reached after 7 days $(8.4 \mathrm{CaO}$ wt. \%) but for wood ash $(\mathrm{J})$ after 28 days $(7.3 \mathrm{CaO}$ wt. \%).

A different curve is reached with pozzolanic activity for shale ashes (I) (crystalline phase - mullite), Figure 3. Pozzolanic activity in first step of treatment in $\mathrm{Ca}(\mathrm{OH})_{2}$ solution (till 14 days) is up to $3.1 \mathrm{CaO}$ wt. \%. A sharp increase in activity for shale ash (I) after 14 days can observed.

The rapid increase in pozzolanic activity of shale ash (I) after 14 days can be explained by a specific character of the crystalline structure of mullite and a structural collapse (an increased amount of reactive $\mathrm{Al}_{2} \mathrm{O}_{3}$ ) by treatment in $\mathrm{Ca}(\mathrm{OH})_{2}$ solution.

The crystal structure of mullite is characterized by chains of edge-connected $\mathrm{AlO}_{6}$ octahedra running parallel to the crystallographic $c$-axis. These very stiff chains are cross-linked by tetrahedral chains consisting of $(\mathrm{Al}, \mathrm{Si}) \mathrm{O}_{4}$ tetrahedra. In mullite some of the oxygen atoms bridging the tetrahedra are removed for charge compensation. This gives rise to the formation of oxygen vacancies and of so-called tetrahedral triclusters (ACI E4, 2003; Aitcin, 2007). Anisotropy of the bonding system of mullite has a major influence on the anisotropy of its physical properties and to chemical durability, in this case to activity. There can be seen formation of amorphous white deposit and XRD test indicated crystalline phase - calcium aluminates, Figure 4.

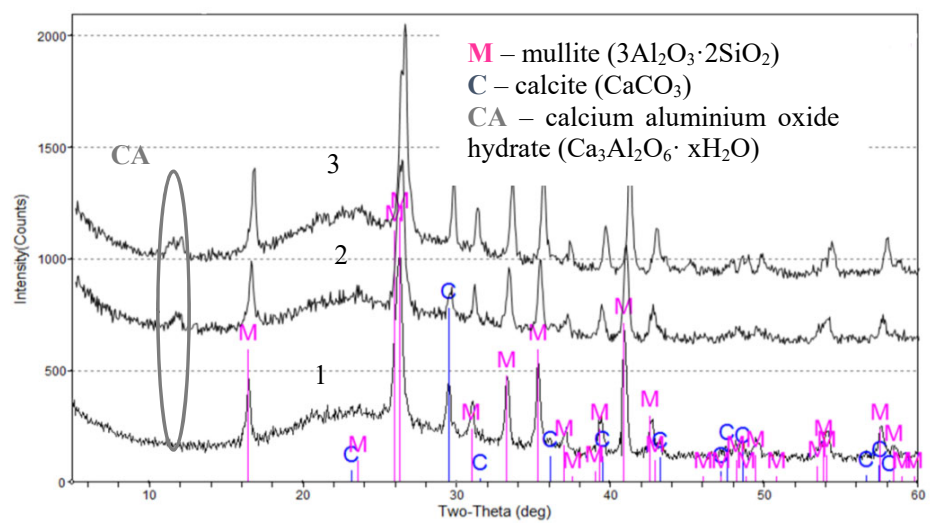

Figure 4. XRD for shale ash (I) after treatment in $\mathrm{Ca}(\mathrm{OH})_{2}$ solution: 1 - 3 days; 2 - 14 days; 3 - 28 days

Properties of fresh ashes paste

Table 5. Properties of fresh ashes paste

\begin{tabular}{|c|c|c|c|}
\hline Test & Wood ash (20JS) & Shale ash (20NS) & Grinded shale ash (20IS) \\
\hline $\mathrm{H}_{2}$ O for $1 \mathrm{~kg}$ ash, $\mathrm{ml}$ & 396 & 270 & 250 \\
\hline Outflow, $\mathrm{mm}$ & 189 & 190 & 195 \\
\hline Density, $\mathrm{kg} / \mathrm{m}^{3}$ & 1773 & 1990 & 1903 \\
\hline Pore volume, $\%$ & 13.4 & 6.2 & 5.6 \\
\hline
\end{tabular}


Paste samples of three types of ashes (20JS, 20NS, 20IS) were mixed with water and outflow on Hagerman flowtable, density and porosity of fresh ashes were evaluated, Table 5. The amount of water was adjusted to each of ash sample to make paste easily moulded and achieve equal outflow of the sample.

There is coherence between fresh paste density and size range. The samples with shale ash (N) had the highest density $\left(1990 \mathrm{~kg} / \mathrm{m}^{2}\right)$ and it had small amount of pores $-6.2 \%$. The lower pore volume of shale ash (I) is associated with the different size of smaller particles $(0.3-12 \mu)$. The smaller particles of ashes can fill pores and decrease pore volume. Accordingly, the sample with wood ash had the lowest density $\left(1773 \mathrm{~kg} / \mathrm{m}^{2}\right)$ and the largest pore content $13.4 \%$. Such result can be explained by the fact that shale ashes are fine and are able to fill the pores of material so the formed mass was denser.

\section{The interaction of ashes with mineral materials}

Investigation of behaviour of wood $(\mathrm{J})$ and shale $(\mathrm{N}, \mathrm{I})$ ashes paste with cement and typical additive of concrete was observed after 1, 3, 5 moths. SEM images show formation of hydrated amorphous needle-like structure for mix composition ashes with sand, Figure 5. Similar structural changes also can be observed in samples with dolomite and limestone. The high $\mathrm{CaO}$ content for ashes affects and defines both crystalline and amorphous structures. There could be indicated the formation of calcium silicate-hydrate $(\mathrm{J}, \mathrm{N})$, but for shale ash (I) the formation of calcium aluminiumhydrate. A small number of crystalline form of calcium silicate-hydrate was detected in 40NS samples after 6 months. Proportionally to hydration time, structure density of sample and the amorphous phase proportion was increased.

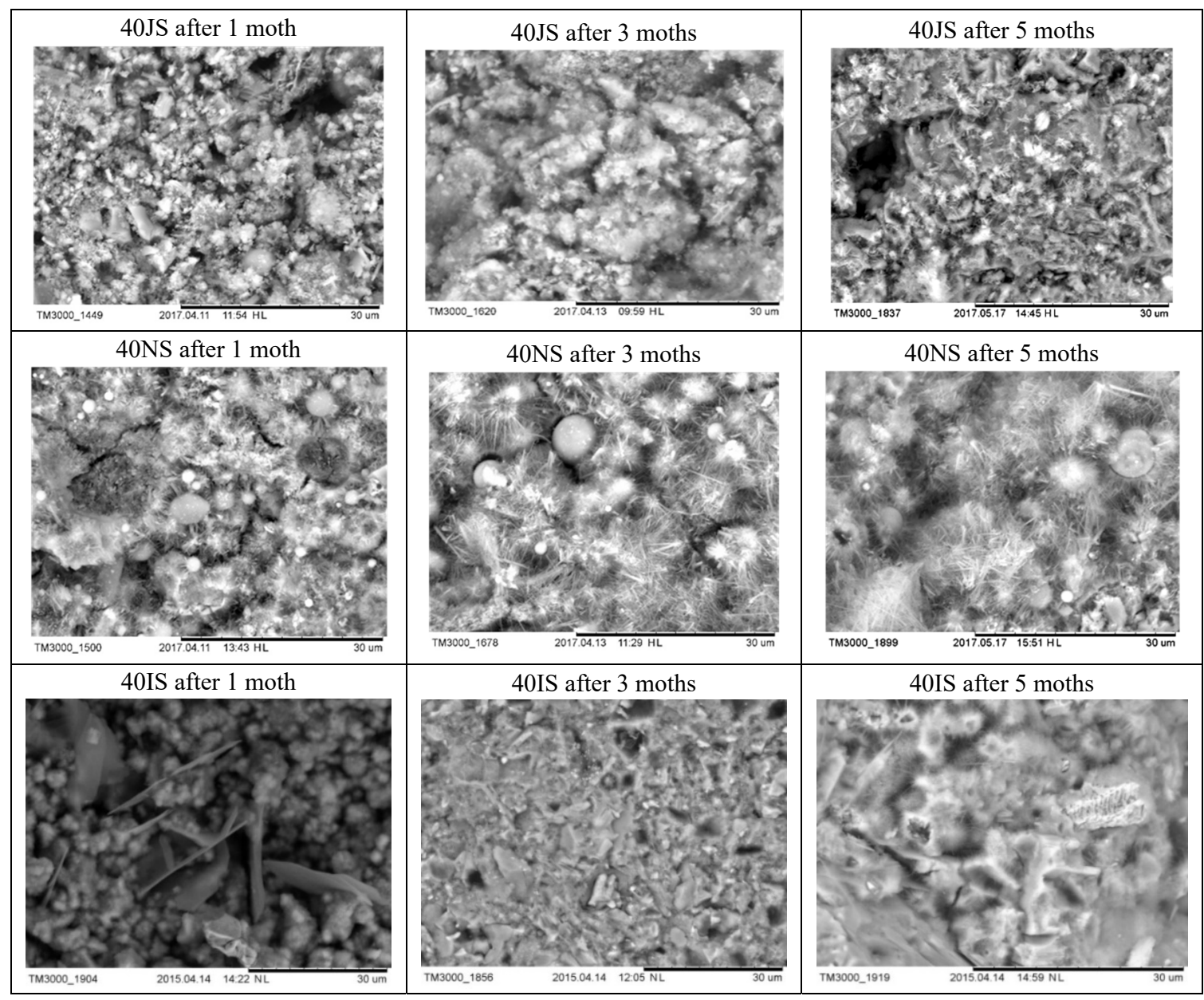

Figure 5. SEM for mix composition: wood (J), shale $(\mathrm{N})$ and $(\mathrm{I}))$ ashes - sand

SEM images showed that the interaction processes in compositions ash - mineral materials in the presence of water continue and the amount of calcium silicate-hydrate or calcium aluminium-hydrate increases, resulting in an increase of the physical and chemical properties of compositions.

The analysis for mix composition shale (I) ash - cement after 1 to 5 month of hydration, SEM's images show the presence of portlandite (hexagonal crystals) and calcite - so the cement paste is still an active system (also confirmed by the X-ray analysis performed on this sample), Figure 6. Increased amorphous phase content and formation of needle-shaped crystals (calcium silicate hydrates) are observed. The pattern of samples becomes more uniform as the hydration time increases. 


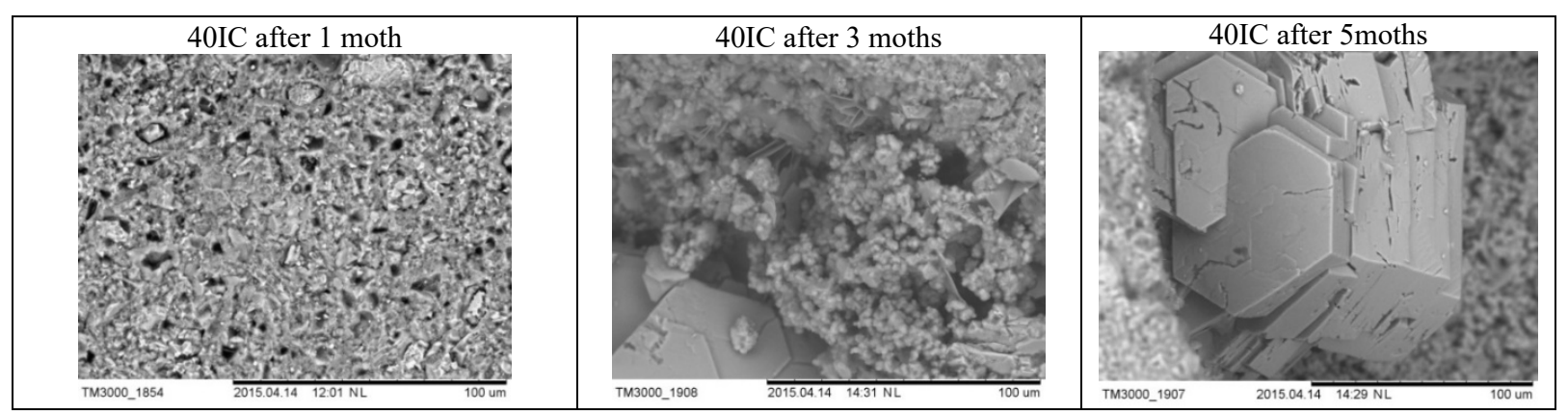

Figure 6. SEM for mix composition shale (I) ash - cement

\section{Properties of dry mix compositions}

\section{Absorption test}

The manufactured samples have been subjected to a water absorbing test with complete immersion. For each composition 4 parallel samples have been used for which the average mass gain has been calculated according to the methodology described. The results obtained are shown as mass gain depending on the time of passage. Initially, all samples show a rapid increase in mass, which is time-equalized, with samples reaching saturation. Water absorption of samples with high content of wood ash (40\%) is not objectively assessable because of the observed weight loss the samples gradually decompose during the test and are not persistent in water.

Visual observation of samples may lead to the conclusion that wood ash with typical concrete additives - sand, dolomite has weak cementing capabilities. When assessing the activity of concrete additives and the absorbing of water, the maximum quantity of ash additive may be up to $20 \%$. When comparing the ashes, samples containing the ashes $(\mathrm{N})$ show a lower water absorption, and no decomposition in the aquatic environment can be observed. The lowest water absorbing is reported by sample $20 \mathrm{NS}$ - an increase of $8.16 \%$ after $24 \mathrm{~h}$. Sample water absorption and weight gain are directly dependent on sample density, which is based on the ash particle size, pozzolanic activity. The structures in which calcium silicate-hydrate or calcium aluminium-hydrate are formed are characterized by a denser structure and higher physical properties. Wood ash and shale ash mixtures with cement showing high pozzolanic activity are characterized by low water absorption. After 24 hours, the weight increase shall not exceed $3.5 \%$.

\section{Compressive strength}

Compressive strength of mix composition cement and concrete additives with three types of ashes are different. Compressive strength of shale ash $(\mathrm{N})$ with sand reaches almost $22 \mathrm{~N} / \mathrm{mm}^{2}$ while compressive strength of wood ash (J) gets $0.2 \mathrm{~N} / \mathrm{mm}^{2}$. This can be explained by evaluating the chemical composition of ashes, the amount of active components. Three types of ashes samples contain different quantity of active $\mathrm{SiO}_{2}+\mathrm{Al}_{2} \mathrm{O}_{3}$. The active components for mixtures with wood ash $(\mathrm{J})$ have a content of only $4.58 \mathrm{wt} . \%$, with shale ashes $(\mathrm{N})$ of $23 \mathrm{wt} . \%$ and with (I) 46 wt.\% respectively, Figure 7 . The size of active surface and active components of interaction ash and mineral raw materials could influence mechanical strength (formation of calcium silicate-hydrate phase and calcium aluminate-hydrate).

Compositions with cement are characterized by higher compressive strength, up to $70 \mathrm{~N} / \mathrm{mm}^{2}$. It is due to intense interaction between components in this mixture, formation both amorphous and crystalline calcium silicate-hydrate. According to the chemical composition, significant cementing properties are presented by shale ashes ( $\mathrm{N}$ and I), which is considered to be expressed in the mechanical properties of the samples.

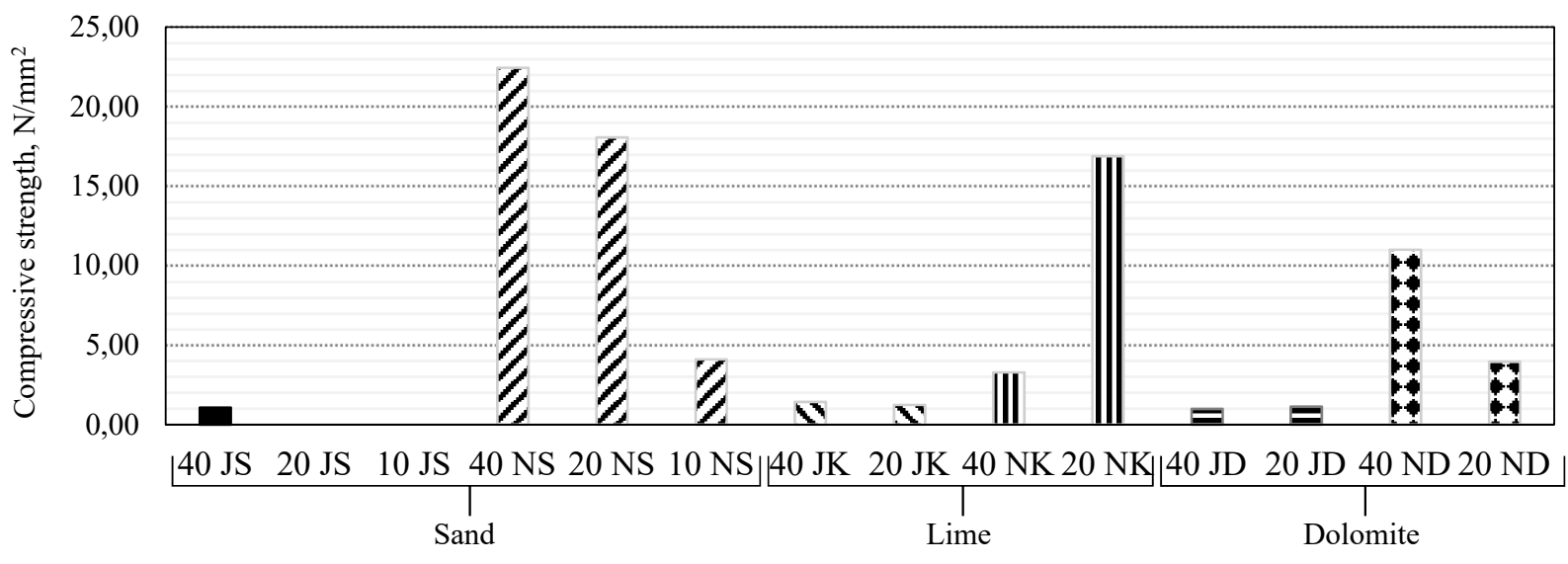

Figure 7. Compressive strength of hardened mix compositions 


\section{Frost resistance}

Each cycle of frost resistance lasted for 24 hours -8 hours in a freezer at temperature $-15^{\circ} \mathrm{C}$ to $-20^{\circ} \mathrm{C}$ and 16 hours of thawing in water at the room temperature $+20^{\circ} \mathrm{C}$. During the frost resistance test samples of wood ash $(\mathrm{J})$ with all mineral raw materials after $2 . .7$ cycle began losing mass and crumbled gradually. Samples of shale ash (N) with sand were stable till 12 cycles, but dolomite containing samples till 18 cycles. The reason - formation of calcium silicate-hydrate phase in composition shale ash + sand or ash + dolomite. Similar samples cement + wood or shale ashes showed high frost resistance. No visual changes of surface were observed in tested cement samples after 24 cycles.

\section{Conclusions}

The influence of shale and wood ashes to the structure and properties of cement and typical concrete additives (sand, lime and dolomite) was studied.

Tested shale ashes exhibit higher pozzolanic activity in the cement and typical additive to concrete paste as compared with activity of wood ash. Observable hydrated amorphous needle-like structure of calcium silicate-hydrate forms during hydration of shale ash $(\mathrm{N})$ and wood ash $(\mathrm{J})$ mixtures with sand, lime and dolomite after 1, 3 and 5 months. The presence of shale ash (I) leads to indicative formation of calcium silicate-hydrate and calcium aluminatehydrate and the presence of portlandite and calcite. Cement paste with shale ashes remain hydration activity after 5 months. The concentration of amorphous phases increases by increasing the duration of hydration and XRD pattern becomes more uniform. The high content of $\mathrm{CaO}$ in ashes affects both the formation of crystalline and amorphous structures during hydration. The density of structure and the ratio of amorphous phases increase proportionally to the duration of hydration.

Shale ashes mix composition samples exhibit a higher density, mechanical strength, frost resistance and lower water absorption, if to compare with wood ashes samples.

It could be concluded that the interaction of tested ashes with cement and typical concrete additives depends on chemical composition. Wood ash could be recommended as reinforcing filler in concrete, but shale ashes exhibit pozzolanic activity beneficial for additional cementitious reactions in cement paste-based concrete structure.

\section{References}

Aitcin, P. C. (2007). Binders for durable and sustainable concrete (1 $1^{\text {st }}$ ed., Modern concrete technology, 16). CRC Press, Taylor \& Francis.

American Coal Ash Association. A. C. A. (2003, June 13). Fly ash facts for highway engineers (Report No FHWA-IF-03-019). Washington, DC. Retrieved from https://pdhonline.com/courses/c535/Fly\%20Ash\%20FHWA\%20report.pdf

American Concrete Institute. (2003). Chemical admixtures for concrete (ACI E4). Farmington Hills.

Ayub, T., Shafiq, N., \& Khan, S. (2013). Durability of concrete with different mineral admixtures: A comparative review. World Academy of Science. Engineering and Technology International Journal of Civil Science and Engineering, 7(8), 1161-1172.

Chowdhury, S., Mishra, M., \& Suganya, O. (2015). The incorporation of wood waste ash as a partial cement replacement material for making structural grade concrete: An overview. Ain Shams Engineering Journal, 6(2), 429-437. https://doi.org/10.1016/j.asej.2014.11.005

Fenelonov, V., Mel'gunov, M., \& Parmon, V. (2010). The properties of cenospheres and the mechanism of their formation during high-temperature coal combustion at thermal power plants. KONA Powder and Particle Journal, 28, 189-208. https://doi.org/10.14356/kona.2010017

Jain, N. (2012). Effect of nonpozzolanic and pozzolanic mineral admixtures on the hydration behavior of ordinary Portland cement. Construction and Building Materials, 27(1), 39-44. https://doi.org/10.1016/j.conbuildmat.2011.08.006

Jozic, D., \& Zelic, J. (2006). The effect of fly ash on cement hydration in aqueous suspensions. Ceramics Silikaty, 50(2):98-105.

Landman, A. A. (2005). Literature review about fly ash in: Aspects of solid-state chemistry of fly ash and ultramarine pigments ( $\mathrm{PhD}$ thesis). Pretoria.

Lilkov, V., Djabarov, N., Bechev, G., \& Petrov, O. (1999). Properties and hydration products of lightweight and expansive cements Part II. Cement and Concrete Research, 29(10), 1641-1646. https://doi.org/10.1016/S0008-8846(99)00149-0

Massazza, M. F. (1980). Structure of pozzolana and fly-ash and the hydratation of pozzolanic and fly ash cements. In $7^{\text {th }}$ International Congress on Chemistry of Cement (pp. 85-91). Paris.

Obernberger, I., \& Supancic, K. (2009). Possibilities of ash utilization from biomass combustion plants. Proceedings of the $17^{\text {th }}$ European Biomass Conference and Exhibition (pp. 2373-2384).

Sear, L. K. A. (2001). Properties and use of coal fly ash: A valuable industrial by-product. Thomas Telford, London.

Siddique, R. (2012). Utilization of wood ash in concrete manufacturing. Resources, Conservation and Recycling, 67, 27-33. https://doi.org/10.1016/j.resconrec.2012.07.004

Wesche, K. (1991). Fly ash in concrete: Properties and performance. Taylor \& Francis, Abingdon.

Zaetang, Y., Wongsa, A., Sata, V., \& Chindaprasirt, P. (2013). Use of lightweight aggregates in pervious concrete. Construction and Building Materials, 48, 585-591. https://doi.org/10.1016/j.conbuildmat.2013.07.077 